\title{
Commercial photovoltaic system design for Cardiff City Hall
}

1 Tracy K. N. Sweet BSC (Hons), PhD, CChem, MRSC Research Associate, Cardiff School of Engineering, Cardiff University, Cardiff, UK

2 Kifah El Khatib MSC Cardiff School of Engineering, Cardiff University, Cardiff, UK

3 Noel Bristow MSC

Managing Director, Centre for Lifetime and Reliability Testing (CLARET), School of Electronic Engineering, Bangor University, Bangor, Gwynedd, UK
4 Brian Drysdale BSc, MBA, MSc, PhD, MRICS Cardiff School of Engineering, Cardiff University, Cardiff, UK

5 Nick Jenkins PhD, FREng, FIEEE, FIET, FLSW Professor, Cardiff School of Engineering, Cardiff University, Cardiff, UK
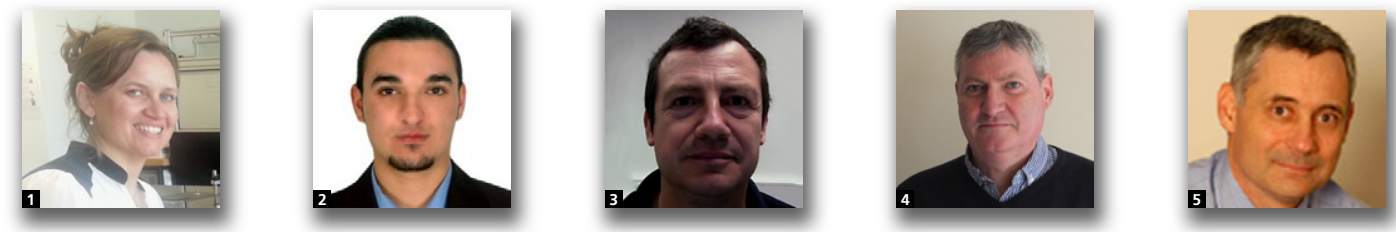

The rooftops of Cardiff City Hall were surveyed to establish potential areas for commercial-scale photovoltaic (PV) system design. The orientation and tilt angles of suitable unshaded roof areas were measured for accurate PV system simulation. The performance of two PV technologies, polycrystalline silicon ( $\mathrm{p}-\mathrm{Si}$ ) and heterojunction with intrinsic thin layers (HIT) was investigated. From the analysis of simulation, experimental, environmental and economic data, HIT was found to be the best-performing PV technology for system installation. Superior performance of HIT under diffuse sunlight conditions, typical of the UK climate, was demonstrated. Additionally, the maximum power temperature coefficient, verified during experimental work, was lower than the p-Si alternative (-0.28 against $-0.50 \% /{ }^{\circ} \mathrm{C}$ ). Electricity demand data for City Hall were analysed and $8.1 \%$ of the annual electricity demand (solar fraction) could be supplied by an 88 kWp HIT PV system. The HIT PV system modelled would significantly improve the energy performance of Cardiff City Hall, avoiding $>40000 \mathrm{~kg}$ carbon dioxide emissions annually. The levelised cost of energy from one array $(B, f 0 \cdot 11 / k W h)$ was less than the current day tariff rate for grid import (f0.1173). The economic and environmental benefits of well-designed high-efficiency PV systems in the UK at commercial scale are also demonstrated.

\section{Introduction}

The UK government introduced the feed-in-tariff (FiT) in April 2010 to incentivise uptake of renewable energy technologies (DECC, 2014a). Small domestic systems for houses $(<4 \mathrm{kWp})$ currently dominate the UK photovoltaic (PV) generating capacity in combination with the recent surge in large solar farm (>1 MWp) deployment. Current UK government figures state that renewables (wind and solar energy) have increased the market share of electricity generation from $15 \cdot 9 \%(2013 \mathrm{Q} 2)$ to $16 \cdot 8 \%(2014 \mathrm{Q} 2)$, against a $0 \cdot 5 \%$ increase in commercial demand from $24 \cdot 7$ to $24.8 \mathrm{TWh}$, with a total UK demand of $71.7 \mathrm{TWh}$ (2014 Q2) (DECC, 2014b)
Legislative targets of $15 \%$ renewable energy generation of all UK gross energy final consumption were set for 2020, and deployment ambitions for PV have recently increased to $10-12$ GWp of installed PV generating capacity by the end of 2020 (DECC, 2013). Commercial buildings account for $25 \%$ of UK's carbon dioxide $\left(\mathrm{CO}_{2}\right)$ emissions, emitting more than 100 Mt of carbon dioxide per annum.

Public buildings must comply with statutory legislation, including Standard Assessment Procedure and Energy Performance Certification (EPC), which connect issues of sustainability, energy efficiency and carbon dioxide emissions (Centre for Alternative Technology, 2010). Public buildings are required to 
Energy

Volume 169 Issue EN1
Commercial photovoltaic system design

for Cardiff City Hall

Sweet, El Khatib, Bristow, Drysdale and

Jenkins have display energy certificates (DECs) prominently on show to promote general awareness of the energy performance of the building. DECs are based on actual energy performance and are rated on a scale of $A-G$ (A is the most and $G$ the least efficient performance). Cardiff's City Hall was built in the early 1900s and has $14165 \mathrm{~m}^{2}$ of usable floor area on three floors. Natural gas heating is provided to the 293 occupants by way of a central steam boiler. City Hall has a typical annual energy consumption of $119 \mathrm{kWh} /\left(\mathrm{m}^{2}\right.$ year $)$ for heating and $95 \mathrm{kWh} /\left(\mathrm{m}^{2}\right.$ year $)$ for electricity. City Hall currently has no contribution from renewable sources for energy supply and has poor energy performance rating (band $\mathrm{E}$ ).

Despite ambitious targets for PV deployment, mid-sized PV installations on commercial and industrial premises accounted for only $6 \%$ of the total installed UK PV capacity at the end of 2013 (UK solar strategy part 2 (DECC, 2014c)). However, these buildings are usually occupied during the hours of daylight, correlating well with PV power profiles where maximum power generation occurs around solar noon/midday. Instantaneous use of PV power produced in situ on the building as a 'prosumer' (producer and consumer) reduces transmission and distribution losses and costs associated with gridimported electricity. PV system installations are readily scalable to any commercial roof area due to the modular nature of PV panels widely available in various technologies, sizes and efficiencies. Power electronics within inverters are used to convert the direct current (DC) produced from the PV array(s) to alternating current (AC) for grid connection, and are widely available in a variety of topologies, capacities and efficiencies. Typically, an inverter consists of a maximum power point tracking (MPPT) circuit to maximise power generation from the string of modules, an energy storage element (e.g. capacitor), a
DC:DC converter to increase the voltage, a DC:AC inverter, an isolation transformer (to prevent DC feed into the grid) and an output filter to restrict harmonic currents (Jenkins et al., 2010).

The current barriers to commercial-scale PV system adoption are cost of installation, short-term return on investment, cost and availability of grid connection, tenant leasing of premises, general lack of technology awareness and investor confidence. Of prime importance to historically important buildings such as City Hall are the architectural and aesthetic considerations of the building's change of appearance after retrofit PV array installation (Gupta et al., 2014). As a complex historical listed building with different roof structures, geometries and nonoptimum tilted roof orientations, there are many options for retrofitted PV system design for City Hall (Figure 1(a)). Site surveys identified the potential rooftops for PV array installation, with their corresponding inclination angles, orientations (azimuth angle) and surface area. The proposed PV system design comprises six feasible roof areas that were not significantly shaded or visible from the front of the building. Solar modules electrically connected in series or parallel (to produce either higher voltage or current) to produce strings in arrays were modelled. The rooftop plan of the PV module arrays is shown schematically in Figure 1(b) with the technical details given in Table 1.

Commercial heterojunction with intrinsic thin layers (HIT) and polycrystalline silicon ( $\mathrm{p}-\mathrm{Si}$ ) modules were simulated with the software PVSOL v7 (Valentin EnergieSoftware, 2014) for annual energy generation estimates. Additionally, PV module performance monitoring experiments were set up on the third floor of Cardiff University's school of Engineering at an

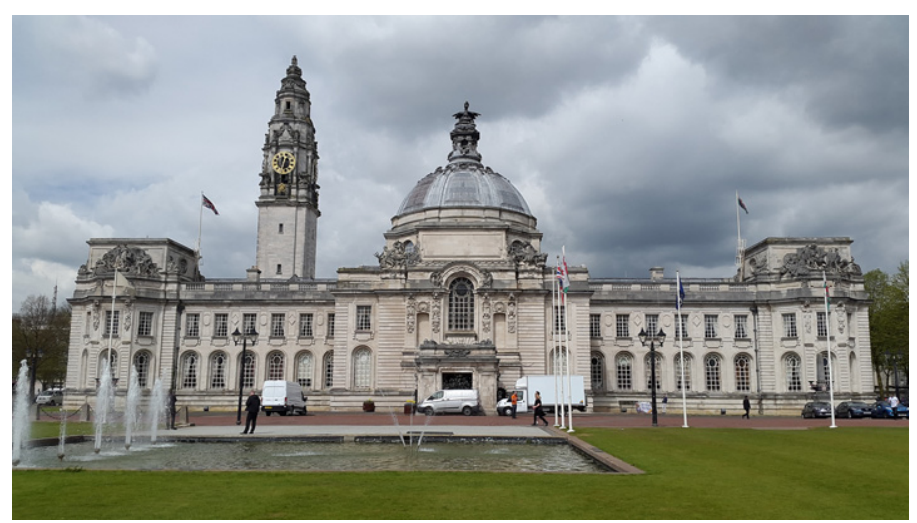

(a)

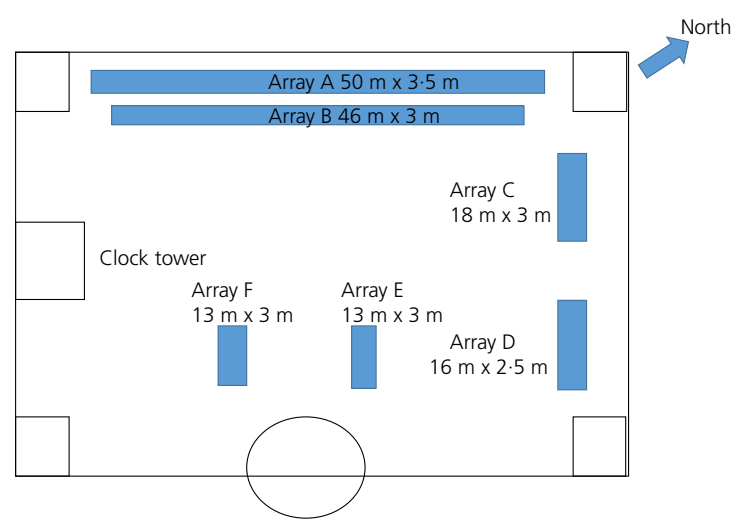

(b)

Figure 1. Cardiff City Hall: (a) front elevation and (b) proposed rooftop PV arrays 


\begin{tabular}{|c|c|c|c|c|c|c|}
\hline Array & $\begin{array}{c}\text { Azimuth } \\
\text { angle: degrees }\end{array}$ & $\begin{array}{l}\text { Roof tilt } \\
\text { angle: degrees }\end{array}$ & $\begin{array}{l}\text { Azimuth angle in } \\
\text { simulations: degrees }\end{array}$ & $\begin{array}{c}\text { Tilt angle in } \\
\text { simulations: degrees }\end{array}$ & $\begin{array}{l}\text { Roof survey: } \\
L(\mathrm{~m}) \times W(\mathrm{~m})\end{array}$ & $\begin{array}{l}\text { Active } \\
\text { area } \mathrm{m}^{2}\end{array}$ \\
\hline$A$ & -39 & 30 & -39 & 30 & $50 \times 3.5$ & 175 \\
\hline$B$ & -39 & 0 (flat roof) & -39 & 33 & $46 \times 3$ & 138 \\
\hline $\mathrm{C}$ & 54 & 60 & 54 & 60 & $18 \times 3$ & 54 \\
\hline$D$ & 54 & 60 & 54 & 60 & $16 \times 2.5$ & 40 \\
\hline $\mathrm{E}$ & -39 & 0 (flat roof) & -39 & 33 & $13 \times 3$ & 39 \\
\hline $\mathrm{F}$ & 54 & 0 (flat roof) & 54 & 28 & $13 \times 3$ & 39 \\
\hline
\end{tabular}

Table 1. Solar PV string details

approximately equivalent altitude to the rooftops of City Hall (geographically $600 \mathrm{~m}$ from Cardiff City Hall). The orientation (azimuth) and tilt angles were used as measured during the site survey of the rooftops, listed in Table 1. Meteorological Office annual incident solar radiation (insolation) data for Cardiff typically lie between 1051 and $1100 \mathrm{kWh} / \mathrm{m}^{2}$ which is comparatively high for the UK, with the benefit of a comparatively low average ambient temperature $\left(9 \cdot 8^{\circ} \mathrm{C}\right)$. In the northern hemisphere, the ideal orientation for maximum PV power generation is south facing. Identification of the best PV technology was concluded from the analysis of simulation, experimental, environmental and economic data.

\section{Experiment}

The experiments were conducted on one brand new VBHN240 HIT module (Panasonic, 2014) and three $~ 5$-year-old BP Solar BP380 80W series connected p-Si modules (BP, 2010), both set-ups generating a maximum of $240 \mathrm{Wp}$. HIT is a relatively recent PV technology, developed over the last decade, combining monocrystalline silicon with a thin layer of amorphous silicon. The manufacturer's product data quote cell efficiencies of $22 \%$ and module efficiencies of $19 \cdot 4 \%$ (Panasonic, 2014). The polycrystalline silicon modules used for previous experimentation had a quoted manufacturer's efficiency of $12.3 \%$ (BP, 2010). An Egnitec PVMS250 monitoring unit (Bristow, 2013) shown in Figure 2 incorporates a maximum power tracker (MPPT). A data logger was used to record daily $I-V$ values sampled in $1 \mathrm{~min}$ intervals from 08:00 to 20:00. The Egnitec unit was constructed with the electrical specifications $P_{\max }=250 \mathrm{~W}, V_{\max }=80 \mathrm{~V}$ and $I_{\max }=12 \mathrm{~A}$. The Egnitec unit connected the solar output to a $10 \Omega$ load bank with series RS422 connectivity. The unit was operated in MPPT, opencircuit and short-circuit modes to monitor the performance of the modules. A PT100 temperature sensor (sensitivity $\pm 0 \cdot 1^{\circ} \mathrm{C}$ ) was used for temperature recording which was physically contacted to the rear of the PV panel.

The solar irradiance was measured by way of a calibrated CM11 Kipp and Zonen pyranometer installed at the module's rack parallel to its surface. The technical data of the PV modules used in the experiments are given in Table 2. Experiments conducted with their corresponding time intervals are given in Table 3.

\subsection{Current-voltage $(I-V)$ measurements}

The experimentally measured $I-V$ curves were obtained under irradiance levels of $100-800 \mathrm{~W} / \mathrm{m}^{2}$, given in Figure 3, and correspond to (a) HIT technology and $(b) \mathrm{p}-\mathrm{Si}$.

As expected, the short-circuit current $\left(I_{\mathrm{SC}}\right)$ increases linearly with increasing irradiance levels, with the HIT having an $I_{\mathrm{SC}}$ of $5 \mathrm{~A}$ and the p-Si having an $I_{\mathrm{SC}}$ of $5.15 \mathrm{~A}$ at $800 \mathrm{~W} / \mathrm{m}^{2}$. Open-circuit voltage $\left(V_{\mathrm{OC}}\right)$ only increases very slightly at higher irradiance levels, with the $V_{\text {OC }}$ for HIT increasing from 48 to $49 \cdot 5 \mathrm{~V}$ and the $V_{\mathrm{OC}}$ for p-Si increasing from 58 to $62 \mathrm{~V}$

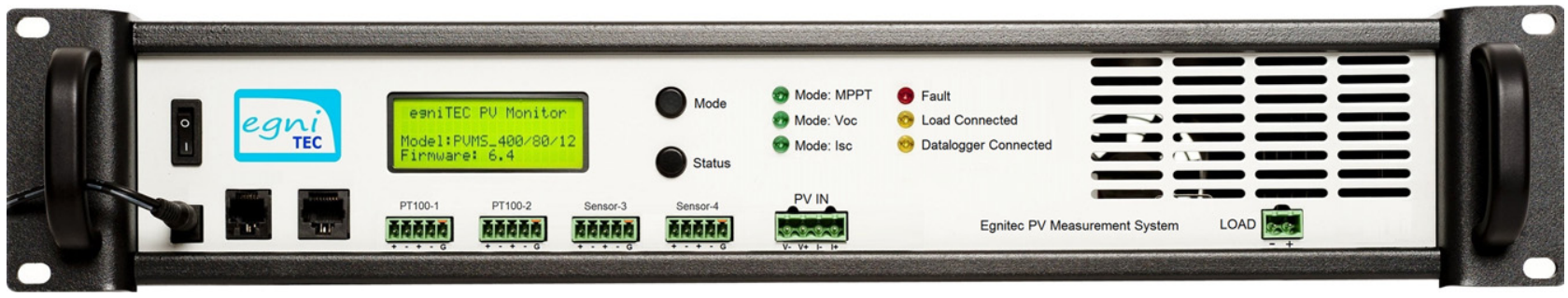

Figure 2. Egnitec PVMS250 diagram (Bristow, 2013) 


\begin{tabular}{|c|c|c|c|c|}
\hline & \multicolumn{2}{|c|}{ VBHN240SJ25 (Panasonic) } & \multicolumn{2}{|c|}{ BP380J (BP Solar) } \\
\hline & $\mathrm{NOCT}$ & STC & NOCT & STC \\
\hline$P_{\max }: \mathrm{W}$ & $183 \cdot 2$ & $240 \cdot 0$ & $57 \cdot 6$ & $80 \cdot 0$ \\
\hline$V_{\mathrm{MP}}: \mathrm{V}$ & $41 \cdot 7$ & $43 \cdot 6$ & $15 \cdot 7$ & $17 \cdot 6$ \\
\hline$I_{\mathrm{MP}}: \mathrm{A}$ & $4 \cdot 4$ & 5.5 & $3 \cdot 6$ & 4.5 \\
\hline$V_{O C}: V$ & $49 \cdot 7$ & $52 \cdot 4$ & $20 \cdot 1$ & $22 \cdot 1$ \\
\hline$I_{s c}: A$ & $4 \cdot 7$ & $5 \cdot 8$ & 3.9 & 4.8 \\
\hline Efficiency: \% & - & $19 \cdot 4$ & - & $12 \cdot 3$ \\
\hline Cell type & \multicolumn{2}{|c|}{ HIT } & \multicolumn{2}{|c|}{ Polycrystalline silicon } \\
\hline Number of cells/bypass diode & \multicolumn{2}{|c|}{$72 / 3$} & \multicolumn{2}{|c|}{$36 / 2$} \\
\hline Weight: kg & \multicolumn{2}{|c|}{$15 \cdot 0$} & \multicolumn{2}{|c|}{$7 \cdot 7$} \\
\hline Area: $\mathrm{m}^{2}$ & \multicolumn{2}{|c|}{$1 \cdot 26$} & \multicolumn{2}{|c|}{0.65} \\
\hline$P_{\max }$ temperature coefficient: $\% /{ }^{\circ} \mathrm{C}$ & \multirow{2}{*}{\multicolumn{2}{|c|}{$-0 \cdot 29$}} & \multicolumn{2}{|c|}{-0.50} \\
\hline Temperature coefficient: V/ ${ }^{\circ} \mathrm{C}$ & & $-0 \cdot 133$ & \multicolumn{2}{|c|}{0.360} \\
\hline
\end{tabular}

STC, standard test conditions - irradiance of $1000 \mathrm{~W} / \mathrm{m}^{2}$ at $\mathrm{AM} 1.5 \mathrm{G}$ solar spectrum and an air temperature of $25^{\circ} \mathrm{C}$; NOCT, nominal operation cell temperature - irradiance of $800 \mathrm{~W} / \mathrm{m}^{2}$ at $A M 1.5 \mathrm{G}$ solar spectrum and an air temperature of $20^{\circ} \mathrm{C}$ with a wind speed of $1 \mathrm{~m} / \mathrm{s}$

Table 2. PV modules technical details

when the irradiance increases from 100 to $800 \mathrm{~W} / \mathrm{m}^{2}$. The significant difference between the technologies is the fill factor (FF), which is higher for the HIT and does not drop significantly at low irradiance levels. The p-Si technology has a lower $\mathrm{FF}$ across the range of irradiances measured. This drop in FF leads to a drop in efficiency and highlights the advantage of HIT against p-Si under diffuse and low light conditions. These results are consistent with the technological advances of HIT, which include enhanced low light performance due to improved surface passivation. Light-trapping abilities and blue light performance are also improved. A higher and consistent
$\mathrm{FF}$ is due to reductions in carrier recombination losses and improvements in series and shunt resistances (Iftiquar et al., 2013).

The active area of the HIT VBHN240SJ25 module is $1.27 \mathrm{~m}^{2}$ compared with the three BP380J modules with a total active area of $1.92 \mathrm{~m}^{2}$. This allows greater PV generating potential to be installed on sites where the available space is limited, as is the case with Cardiff City Hall. Solar irradiance data were obtained from the Cardiff University weather station (Cardiff University, 2014), situated at the Welsh School of Architecture,

\begin{tabular}{|c|c|c|c|c|}
\hline Experiment & Azimuth: degrees & Tilt: degrees & Date range & \\
\hline \multicolumn{5}{|l|}{ HIT } \\
\hline 1 & -39 & 30 & 09 July & 16 July \\
\hline 2 & -39 & 33 & 17 July & 24 July \\
\hline 3 & 54 & 28 & 24 July & 31 July \\
\hline 4 & 54 & 60 & 01 August & 17 August \\
\hline 5 & Generation optimum angle & & 13 August & 14 August \\
\hline 6 & Temperature effect & & 09 July & 11 July \\
\hline \multicolumn{5}{|l|}{$\mathrm{p}-\mathrm{Si}$} \\
\hline 7 & -39 & 30 & 18 August & 20 August \\
\hline 8 & -39 & 33 & 21 August & 23 August \\
\hline 9 & 54 & 28 & 24 August & 26 August \\
\hline 10 & 54 & 60 & 26 August & 28 August \\
\hline
\end{tabular}

Table 3. List of experiments 


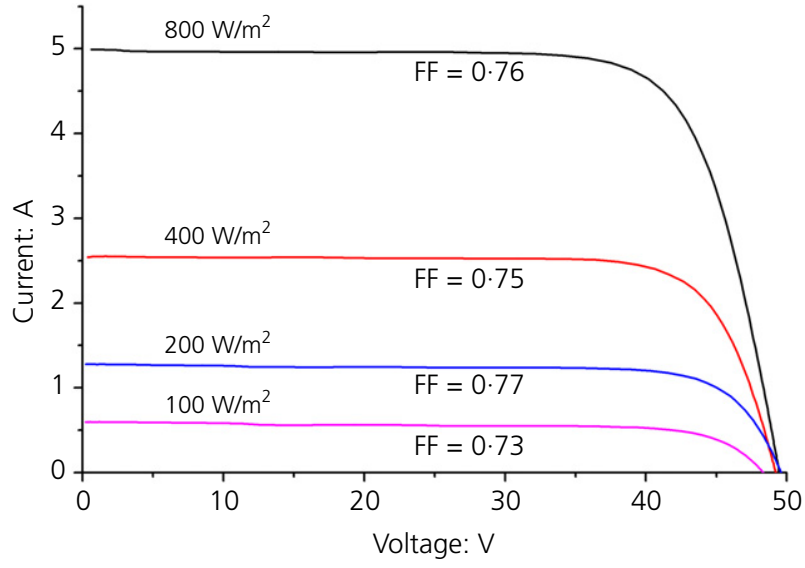

(a)

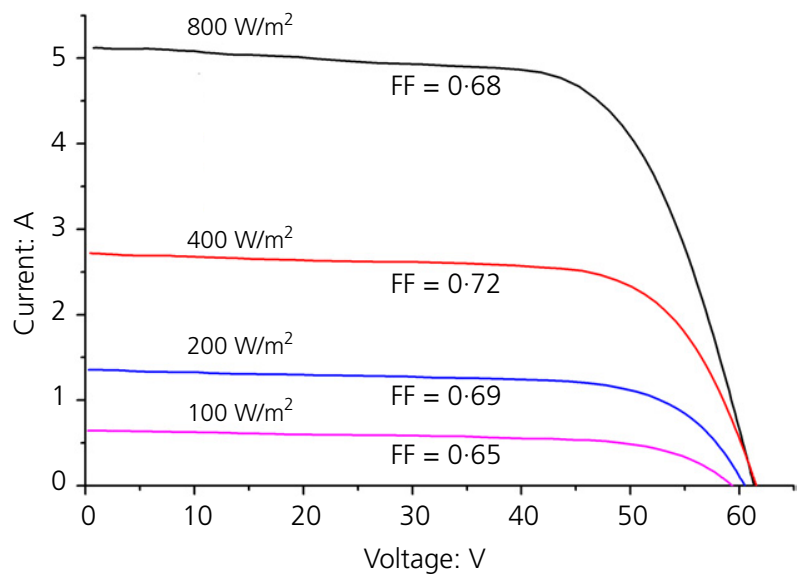

(b)

Figure 3. $I-V$ curves at different irradiance levels for: (a) the HIT panel and (b) the p-Si panels

in close proximity to both Cardiff City Hall and the School of Engineering. The efficiencies of HIT and p-Si technologies were calculated from the experimental results, from Equation 1 , and the results are summarised in Figure 4

1. Efficiency $\eta_{\mathrm{eff}}(\%)=\left[P_{\mathrm{mpp}} /(E \times A)\right] \times 100$

where the maximum power point $\left(P_{\mathrm{mpp}}\right)$ occurs at the knee of the $I-V$ curve, $\left(I_{\mathrm{mpp}} \times V_{\mathrm{mpp}}\right), E$ is the irradiance $\left(\mathrm{W} / \mathrm{m}^{2}\right)$ and $A$ is the active area $\left(\mathrm{m}^{2}\right)$. The incident solar radiation (insolation, $\mathrm{kWh} / \mathrm{m}^{2}$ ) levels were obtained by integrating the recorded irradiance $\left(\mathrm{kW} / \mathrm{m}^{2}\right)$ over time.

Experiments 1-4 relate to HIT experiments and 7-10 relate to $\mathrm{p}$-Si experiments (as listed in Table 3). Higher conversion efficiencies were observed for the HIT technology, as expected from the manufacturer's quoted data. Values of between 18.6 and $19 \cdot 2 \%$ were calculated from experimental measurements $(19 \cdot 4 \%$ is quoted by the manufacturer under standard test conditions (STC)). The highest efficiency was measured with the module azimuth angle corresponding to the westerly orientated rooftops of Cardiff City Hall. The p-Si module efficiencies were calculated between 13 and $13.9 \%$, slightly higher than the manufacturer's quoted efficiency at STC of $12.3 \%$, due to lower experimental cell temperatures than quoted under $\mathrm{STC}, 25^{\circ} \mathrm{C}$.

The effect of temperature on both HIT and p-Si technologies was investigated. As quoted in Table 2, the temperature coefficient for output power is much smaller for HIT than $\mathrm{p}-\mathrm{Si}$ $(-0 \cdot 29 \% / \mathrm{K}$ against $-0 \cdot 5 \% / \mathrm{K})$. The implications of this are that the HIT technology will generate more power during periods

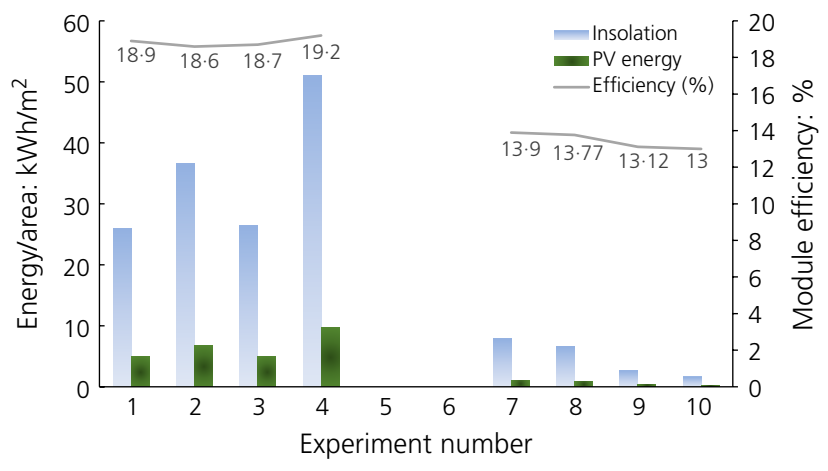

Figure 4. Insolation, PV energy generation and module efficiency against experiment number

of high cell and ambient temperature compared with p-Si. Figure 5 shows the effect of temperature on output power of the HIT module.

Reduction in power output from 239 to $230 \mathrm{~W}$, at an irradiance level of $1000 \mathrm{~W} / \mathrm{m}^{2}$, corresponds to module temperature increase from $26 \cdot 5$ to $40^{\circ} \mathrm{C}$. This provides an experimentally measured temperature coefficient of $-0 \cdot 28 \% / \mathrm{K}$, close to the manufacturer's published value of $-0 \cdot 29 \% / \mathrm{K}$ (Panasonic, 2014). The maximum power output against irradiance for HIT is plotted in Figure 6. It can be seen that the maximum power output increases almost linearly with irradiance. Intermittent cloud cover contributes most to the reduction in the output power of the module, rather than changes in the module's temperature and resistive losses. 
Commercial photovoltaic system design

for Cardiff City Hall

Sweet, El Khatib, Bristow, Drysdale and

Jenkins

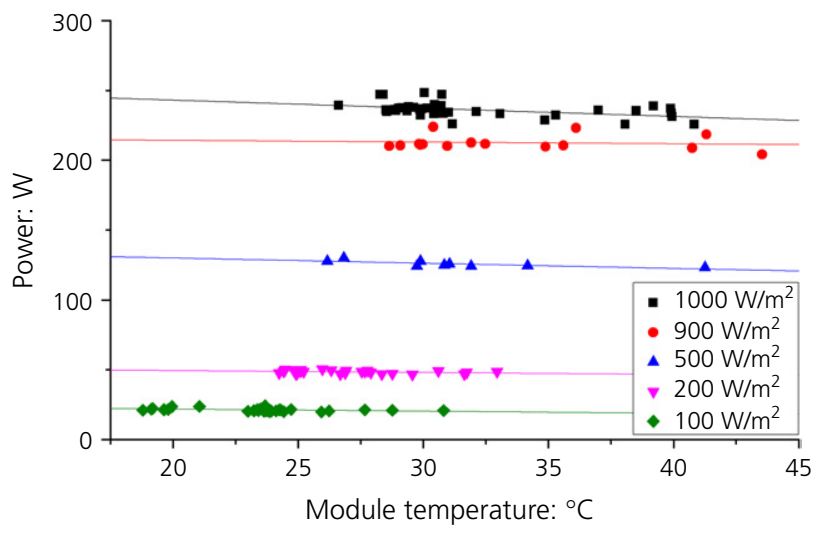

Figure 5. Temperature effect $\left({ }^{\circ} \mathrm{C}\right)$ on the output power $(\mathrm{W})$ of the HIT module

\subsection{Optimum angle experiment}

Cardiff City Hall's rooftops (labelled B, E and F in Figure 1(b) and Table 1) are flat and therefore module mounting racks can be installed at any inclination angle. This enables optimisation of photon energy absorption and power generation through the year. Maximum photon absorption occurs at an angle perpendicular to the module surface. Inclining solar modules increases electricity production from direct normal irradiance, especially significant during spring and summer months (April-August). During experiment 5 (Table 3), the output generation corresponding to 16 surface inclinations $\left(28-58^{\circ} / 2^{\circ}\right.$ increment), was recorded over a short interval of time $(46 \mathrm{~min})$ during the middle of the day. Short intervals were chosen in order to avoid a large change in the sun's position, avoid potential cloud cover and maintain the same irradiance and ambient conditions. With a time span of 3 min per tilt, the difference in

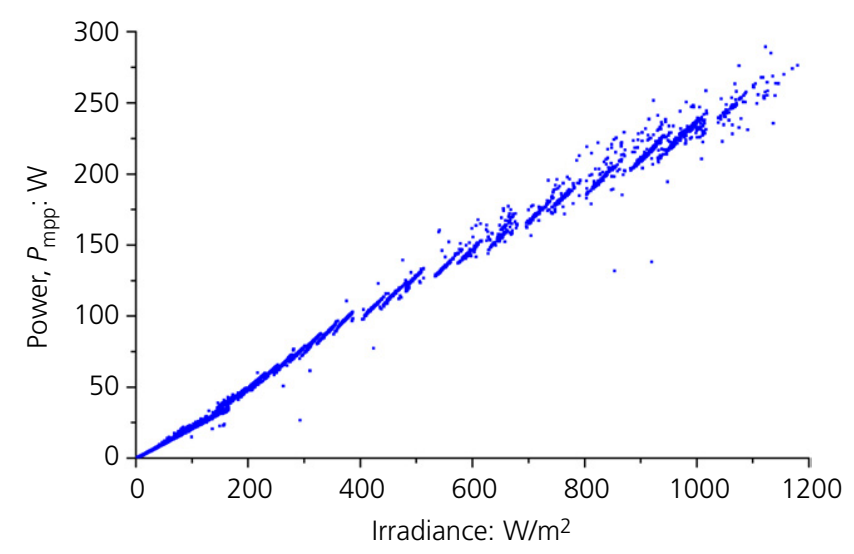

Figure 6. Maximum power point, $P_{\mathrm{mpp}}(\mathrm{W})$, plotted against irradiance $\left(\mathrm{W} / \mathrm{m}^{2}\right)$ for HIT the output energy is quite low at different angles $(<1 \%)$. For an azimuth of $-39^{\circ}$ (corresponding to the City Hall orientation), the maximum generation over the total $46 \mathrm{~min}$ occurred at $36^{\circ}$ inclination (25 July 2014, 14:15-15:02).

\section{Software simulation}

PV system simulations for Cardiff City Hall were carried out using PVSOL v7 (Valentin EnergieSoftware, 2014) where climate data are referenced from the MeteoNorm and MeteoSyn databases (MeteoSyn, 2014). The suitable City Hall rooftop areas with azimuth/inclination angles, as shown in Figure 1 and Table 1, were simulated. Panasonic HIT VBHN240 and BP Solar BP380J p-Si modules were selected, and these modules were also used for experimentation. The maximum number of PV modules was calculated to fit each rooftop area: 370 HIT modules and 745 p-Si modules. The inverter configuration was selected from the commercial database listed within the software. The manufacturer was pre-selected in the software due to their wide range of commercially available inverter sizes and technologies. Sunny Tripower 20000TL-30, 15000TLEE-10, 25000TL-30, 8000TL-20, 7000TL-20 and 5000TL-20 (http://www.sma-uk.com/products/solarinverters. html) were selected in the PV system design for individual rooftop areas. The basic configuration and connection of strings for each PV array were selected. The PV systems were checked for the maximum power point $(\mathrm{V}), V_{\mathrm{OC}}(\mathrm{V})$, current (A), performance and sizing factor. These technical checks were run to ensure that individual strings of PV modules comprising each array, connected to an inverter, would operate within the manufacturer's specifications to give excellent and reliable performance. Finally, simple cabling estimates were input into the simulation to account for the losses associated with the AC cable (meter to inverter), DC main cable and string cables required. The simulation results for each array for both PV technologies are summarised in Table 4. The results comprise peak capacity (the rated power output for each module under STC, multiplied by the number of modules installed, $\mathrm{kWp}$ ), number of panels, AC energy generation (DC power output integrated over time minus losses due to DC:AC conversion, $\mathrm{kWh})$, annual yield $(\mathrm{kWh} / \mathrm{kWp})$ and performance ratio (a measurement of the energy losses within the system that occur in comparison with the system's nominal output, calculated from the solar irradiation onto the tilted PV surface multiplied by the module efficiency under STC).

The fundamental differences between the HIT and p-Si PV module efficiencies and temperature coefficients (Table 2) result in higher capacity, energy generation, annual yield and performance ratio for the HIT system compared with the $\mathrm{p}-\mathrm{Si}$ system. The HIT arrays (A, B, E and F) would achieve very high annual yields of more than $850 \mathrm{kWh} / \mathrm{kWp}$. Arrays $\mathrm{C}$ and $\mathrm{D}$ have lower specific annual yields $(767-810 \mathrm{kWh} / \mathrm{kWp})$ due to non-optimal south-west (SW) orientation. The HIT 


\begin{tabular}{|c|c|c|c|c|c|}
\hline \multicolumn{6}{|c|}{ Array A } \\
\hline HIT & $30 \cdot 72$ & 128 & 26972 & 878 & $83 \cdot 1$ \\
\hline $\mathrm{p}-\mathrm{Si}$ & 21.52 & 269 & 18391 & 855 & 81.8 \\
\hline \multicolumn{6}{|c|}{ Array B } \\
\hline HIT & $26 \cdot 88$ & 112 & 24559 & 914 & $86 \cdot 5$ \\
\hline $\mathrm{p}-\mathrm{Si}$ & 16.96 & 212 & 14958 & 882 & $84 \cdot 4$ \\
\hline \multicolumn{6}{|c|}{ Array C } \\
\hline HIT & 8.64 & 36 & 7000 & 810 & $85 \cdot 4$ \\
\hline $\mathrm{p}-\mathrm{Si}$ & 6.64 & 83 & 5200 & 783 & 83.5 \\
\hline \multicolumn{6}{|c|}{ Array D } \\
\hline HIT & $7 \cdot 20$ & 30 & 5835 & 810 & $85 \cdot 5$ \\
\hline $\mathrm{p}-\mathrm{Si}$ & 4.88 & 61 & 3742 & 767 & $81 \cdot 8$ \\
\hline \multicolumn{6}{|c|}{ Array $\mathrm{E}$} \\
\hline HIT & 7.68 & 32 & 6929 & 902 & $85 \cdot 4$ \\
\hline $\mathrm{p}-\mathrm{Si}$ & 4.80 & 60 & 4134 & 861 & 82.5 \\
\hline \multicolumn{6}{|c|}{ Array $\mathrm{F}$} \\
\hline HIT & 7.68 & 32 & 6768 & 881 & $85 \cdot 2$ \\
\hline $\mathrm{p}-\mathrm{Si}$ & 4.80 & 60 & 4022 & 838 & $82 \cdot 0$ \\
\hline
\end{tabular}

Table 4. HIT and p-Si system simulation results

system, due to higher module efficiency and smaller output temperature coefficient, could achieve a total system capacity of $88.8 \mathrm{kWp}$. The p-Si system would have a much smaller total peak capacity of $59.6 \mathrm{kWp}$. For overall system-specific annual yield, HIT technology gives $879 \mathrm{kWh} / \mathrm{kWp}, 33 \mathrm{kWh} / \mathrm{kWp}$ higher than the p-Si technology at $846 \mathrm{kWh} / \mathrm{kWp}$. In terms of annual energy forecasts, HIT technology would generate $78062 \mathrm{kWh}, 54 \cdot 7 \%$ more energy than $\mathrm{p}-\mathrm{Si}$ technology at $50754 \mathrm{kWh}$.

An offset in the yield estimates was found when comparing experimental and simulation data for both PV technologies. The experimental HIT module conversion efficiency was calculated between 18.6 and $19 \cdot 2 \%$, the output from the PVSOL simulation was $16 \cdot 98 \%$. The $\mathrm{p}$-Si module efficiencies were calculated between 13 and $13.9 \%$, slightly higher than the manufacturer's quoted efficiency (STC) and PVSOL value of $12 \cdot 3 \%$. Commercial solar simulation software packages often slightly underestimate the potential annual PV energy generation. This is primarily due to low irradiance algorithms and estimation of solar radiation, integrated within the geographical information systems over very large areas where inclination, orientation and shadowing effects are extremely important (JRC, 2006). Underestimation of irradiation, mainly due to incremental soiling of measurement instruments such as pyranometers, can produce lower than actual annual climate data and therefore annual energy forecasts from PV systems. PV modules are designed to minimise soiling effects with well-designed and effective transparent hydrophobic 'self-cleaning' encapsulating coatings when inclination angles to the horizontal are $>20^{\circ}$ (Redahan, 2014).

\section{City Hall energy balance}

\subsection{City Hall load data and potential PV energy generation for HIT and $\mathrm{p}$-Si technologies}

The AC electrical energy load data (kWh) of Cardiff City Hall (Carbon Culture, 2014) were downloaded for 2013 and 2014 to assess the relative impact of installing an HIT or p-Si PV system (see Figure 7). The energy demand of the building in 2014 was reduced by $8 \cdot 4 \%$ against 2013 data. The energy balance of the building shows that the monthly energy load greatly exceeds potential PV energy generation, for either HIT or p-Si PV technology. Therefore, adoption of either PV technology would not produce grid export of the renewable energy generated on the rooftop. All PV generation would be consumed by the instantaneous electricity demand of the building. This analysis proves that energy (battery) storage would not be required in the system design. During any power cuts to the building, the PV systems would be inoperable due to antiislanding protection of the inverter(s).

Historically, electrical energy demand reaches maximum levels during the winter and drops to minimum levels during the summer. During January 2014, energy demand reached a maximum, averaging $3436 \mathrm{kWh} / \mathrm{d}$. Energy demand dropped to minimum levels during the months of July to September, averaging between 2643 and $2788 \mathrm{kWh} / \mathrm{d}$. On-site PV power generation 


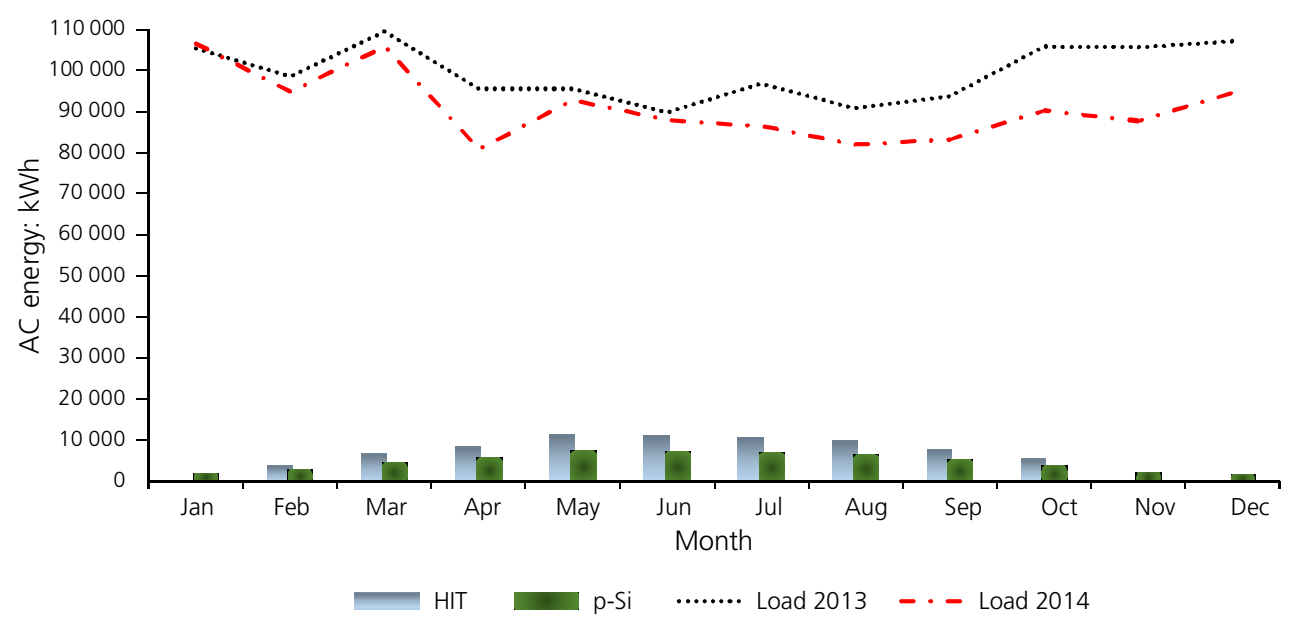

Figure 7. Energy balance, AC energy load (2013 and 2014) and potential PV energy generation

from retro-fitted or building-integrated modules can substantially reduce the amount of grid-supplied electricity imported (Moselle et al., 2010), as shown in Figure 8. The monthly solar fraction is the percentage of energy load supplied by potential PV system generation. The solar fraction is at optimum levels during the summer when PV power generation is at a maximum when the load of the building is at minimum. The solar fraction would reach $13 \cdot 7 \%$ (HIT) and $8 \cdot 5 \%$ (p-Si) for Cardiff City Hall based on June 2014 demand data. Conversely, maximum winter load and minimum PV energy generation gives solar fraction minima of $2 \cdot 1 \%$ (HIT) and $1 \cdot 3 \%$ ( $\mathrm{p}$-Si) during December. To increase the solar fraction through the winter, either the load of the building would need to be further reduced by way of energy-saving initiatives (such as light-emitting diode lighting and low-energy computers). Alternatively, the area for the PV arrays could be increased by exploring further rooftops visible from front of the building, subject to planning approval.

As illustrated in Figure 9, the peak power loads for City Hall are shifted towards the afternoon and evening, 17:50 in summer (21 June 2014) due to evening events and 15:00 in winter (21 December 2014).

Maximum PV power generation for the proposed arrays occurs at different times of the day due to differences in azimuth and inclination angles for the fixed angle rooftops in combination with the sun's trajectory. The impact of the southeast array A was compared with the SW rooftops C and D. Array A would be highly productive through the morning and during solar noon. Conversely, arrays $\mathrm{C}$ and $\mathrm{D}$ become more productive during the afternoon. After 14:00, the energy generated from

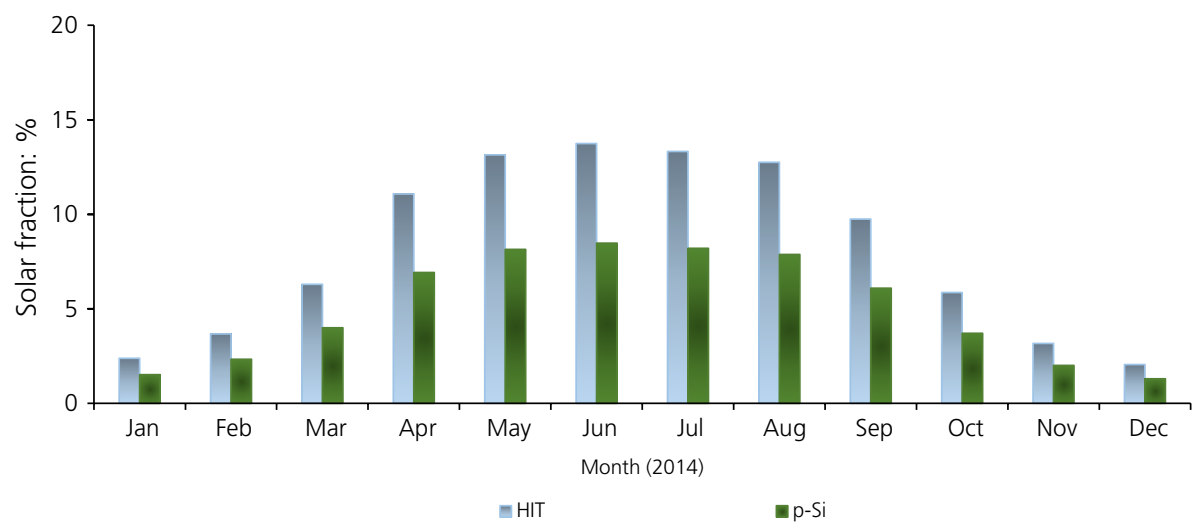

Figure 8. Monthly solar fraction for HIT and p-Si PV technologies 


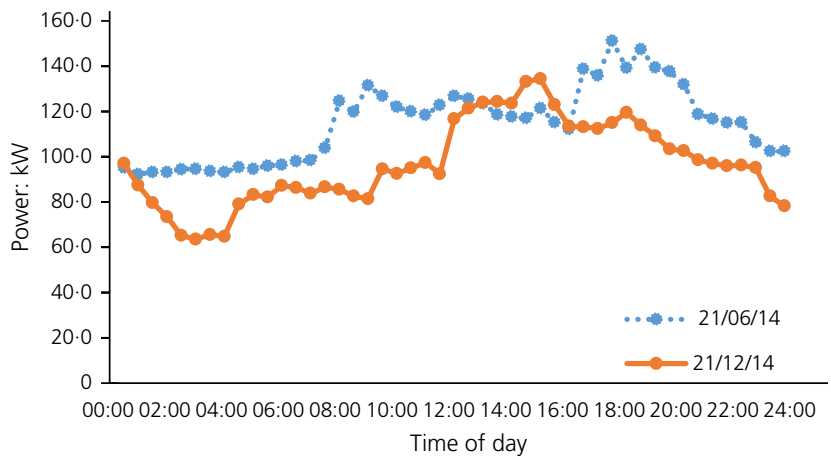

Figure 9. Typical Cardiff City Hall electrical power (kW) demand against time of day for summer (21 June 2014) and winter (21 December 2014)

array A decrease to less than half of energy generated during the morning, while the energy generation increases for arrays $\mathrm{C}$ and D. Although having lower specific annual yield, arrays $\mathrm{C}$ and $\mathrm{D}$ would contribute most to the reduction of peak power demand on the grid at 6 p.m.

\subsection{Carbon footprint of Cardiff City Hall}

Cardiff City Hall's current energy certificate rating is E, with a low comparative efficiency of $114(100$, rating $\mathrm{D}$, is typical for this type of building). The total energy demands in 2013 were $1193313 \mathrm{kWh}$ (electricity) and $3028379 \mathrm{kWh}$ (gas). The total annual carbon dioxide emissions based on 2013 data are $1217 \mathrm{t} /$ year, of which $55 \%$ corresponds to electricity consumption $(667 \mathrm{t} /$ year), $45 \%$ for heating ( $550 \mathrm{t} /$ year), with $0 \%$ energy from renewables. The simulated potential annual savings on carbon dioxide emissions for the two proposed PV technologies are given in table 5.

The DECC conversion factors for company reporting figure $(533 \cdot 1 \mathrm{~g}$ carbon dioxide/ $\mathrm{kWh})$ was taken from Table 6 of Base Electricity Generation Emissions Factors for Company Reporting (DECC, 2014d). The estimated carbon dioxide emissions of the building from grid-imported electricity (combined

\begin{tabular}{lcc}
\hline PV system technology & HIT & p-Si \\
\hline Energy from renewables: kWh & 78062 & 50448 \\
$\begin{array}{l}\text { Carbon dioxide emission reduction: kg/year } \\
\text { Building estimated carbon dioxide emission: } \\
\text { t/year }\end{array}$ & 11614 & 26894 \\
& 1175 & 1190
\end{tabular}

Table 5. Impact of PV system installation on Cardiff City Hall by technology with gas heating) would drop from 1217to 1175 t/year (HIT) or $1190 \mathrm{t} /$ year ( $\mathrm{p}-\mathrm{Si}$ technology). At these levels of carbonised energy, the energy rating of the City Hall would improve from its current level E (114 comparative efficiency) to a typical D rating (76-100).

\section{Economic analysis}

In addition to the technical analysis described above, an analysis was carried out to compare the financial performance of the different technologies using discounted cash flow (DCF)/ net present values (NPV), payback periods and levelised cost of electricity (LCOE) metrics. DCF/NPV calculations discount the future cash flow (costs and income) of a project to take account of risk and the time value of money - that is, immediate cash flow is more valuable than future cash flow. A positive NPV implies a project is worth pursuing, whereas a negative NPV implies the project is not financially viable. Payback period describes the amount of time the project cash flow takes to payback the initial investment. LCOE is the discounted lifetime cost of ownership of using a generation asset converted into an equivalent unit cost of generation ( $£ / \mathrm{MWh}$ or $\mathrm{p} / \mathrm{kWh}$ ). A model was prepared to compare the financial performance of different technologies and arrays using the assumptions shown in Table 6.

The study adopts the FiT payment rates corresponding to eligible installations dated after the 1 July 2014. The electricity import tariff rates (day/night) were supplied by Cardiff City Council. Indicative costs of the solar modules and inverters were based on commercial quotations from leading UK PV equipment suppliers. Due to the pre-existing high-voltage supply to Cardiff City Hall, the cost of connection to the grid, provided by the Distributed Network Operator (Western Power), $£ 525$, would cover the expense of witnessing the final system commissioning. As PV electricity generation never exceeds load demand, the FiT export rate was not considered in the financial model. The financial inputs are current as at Q4 2014. FiT, standard tariff and carbon reduction commitment (CRC) energy efficiency rates are likely to vary in future which may impact on the results. The UK government carbon reduction commitment (Environment Agency, 2015) was included in the model where $550 \mathrm{~g}$ carbon dioxide $/ \mathrm{kWh}$ in year 0 is reduced to $50 \mathrm{~g}$ carbon dioxide/ $\mathrm{kWh}$ in year 25 . The results of the analysis are shown in Table 7.

HIT has a better financial performance than p-Si and arrays $\mathrm{A}, \mathrm{B}$ and $\mathrm{E}$ show a higher return than arrays $\mathrm{C}, \mathrm{D}$ and $\mathrm{F}$ across both technologies. The HIT payback period ranges from 6.7 years (B) to 10.2 years (D). The p-Si payback period ranges from $15 \cdot 0$ (A) to more than 25 years (D). The results for individual arrays are lower than the total per technology due to the disproportionate effect of setting up, access and decommissioning costs. The LCOE for HIT is at a minimum 
Cost per panel (HIT technology)

Cost per panel ( $p$-Si technology)

Discount rate (real)

Installation life

FiT duration

FiT rate

Standard electricity tariff rate (day)

Inverter replacement (50\% of initial cost)

Operating, maintenance and insurance costs

PV degradation rate - HIT

PV degradation rate $-\mathrm{p}$-Si

CRC energy efficiency scheme, cost of carbon dioxide emissions
$£ 201 \cdot 60$

f135.00

$3 \cdot 5 \%$ (HM Treasury, 2011)

25 years

20 years

$9 \cdot 3 \mathrm{p} / \mathrm{kWh}$

$11 \cdot 7278 \mathrm{p} / \mathrm{kWh}$

15 years

$1 \%$ of initial cost per year

$1 \%$ per year

$0.6 \%$ per year

£15.60/t carbon dioxide (Environment Agency, 2014)

Table 6. Economic analysis model input assumptions

\begin{tabular}{|c|c|c|c|c|c|c|}
\hline \multirow[b]{2}{*}{ Array } & \multicolumn{3}{|c|}{ HIT } & \multicolumn{3}{|c|}{$\mathrm{p}-\mathrm{Si}$} \\
\hline & NPV: $f$ & LCOE: f/kWh & Payback: years & $N P V: f$ & LCOE: f/kWh & Payback: years \\
\hline$A$ & 33487 & $0 \cdot 12$ & $7 \cdot 2$ & 1430 & $f 0 \cdot 19$ & $15 \cdot 0$ \\
\hline B & 33219 & $0 \cdot 11$ & $6 \cdot 7$ & -127 & $\mathrm{f} 0 \cdot 20$ & $15 \cdot 6$ \\
\hline C & 5327 & $0 \cdot 15$ & $9 \cdot 4$ & -3859 & $f 0.25$ & $20 \cdot 4$ \\
\hline $\mathrm{D}$ & 3464 & $0 \cdot 16$ & $10 \cdot 2$ & -4373 & $\mathrm{f} 0.27$ & $\mathrm{~N} / \mathrm{A}$ \\
\hline$E$ & 6243 & $0 \cdot 14$ & $8 \cdot 7$ & -3008 & $\mathrm{f} 0.25$ & $20 \cdot 1$ \\
\hline $\mathrm{F}$ & 5765 & $0 \cdot 14$ & $9 \cdot 0$ & -3353 & $f 0.25$ & $21 \cdot 6$ \\
\hline
\end{tabular}

Table 7. Results of economic analysis model

for array $\mathrm{B}(£ 0 \cdot 11 / \mathrm{kWh})$, less than the day tariff rate for grid import, and maximum for D $(£ 0 \cdot 16 / \mathrm{kWh})$. LCOE for $\mathrm{p}-\mathrm{Si}$ ranges from $(£ 0 \cdot 19 / \mathrm{kWh})$ for $A$ to $(£ 0 \cdot 27 / \mathrm{kWh})$ for $\mathrm{D}$.

\section{Discussion}

The main barrier to adoption of PV has historically been due to the high initial cost of the system (PV modules, inverters and the balance of systems together with installation costs). However, a strong growth in the sector stimulated by financial incentives (FiT and renewables obligation) has driven down costs by $\sim 70 \%$ over the past 5 years in the UK. This case study demonstrates that PV installations can be environmentally and economically feasible for commercial-scale buildings. Renewable energy utilisation can be used effectively to reduce carbon dioxide emissions and therefore improve the EPC of existing building stock. This paper summarises the findings from two PV genres, mature ( $\mathrm{p}-\mathrm{Si}$ ) against recently emergent (HIT) technology. Alternative commercially available technologies could be investigated in future studies. Current government estimates state that solar energy could provide at least $4 \%$ of UK electricity by 2020 . The potential for using large commercial building rooftops for solar energy generation is extremely promising both in the UK and globally. Power is used where it is produced minimising transmission and distribution losses. Time of use is mostly during the daytime which synchronises with PV power generation profiles, and no pollution is emitted. PV systems have minimal maintenance requirements. Finally, with respect to planning permission, PV technology is silent and arrays can be quickly and reversibly installed on current rooftop areas.

\section{Conclusions}

The rooftops of Cardiff City Hall investigated in this case study could be used for PV energy generation, reducing the building's considerable grid demand (1193 MWh p.a. based on 2013 load data, 1093 MWh p.a. based on 2014 load data). The grid-imported electricity could be reduced by $8 \cdot 1 \%$ p.a. based on HIT technology and 2014 load data. Arrays A and B would have higher financial return across both technologies, partly due to a flat day grid-import tariff rate from 07:00 to 00:00. The calculated HIT payback period ranged from 6.7 years (B) to 10.2 years (D), while the p-Si payback period ranged from 15.0 years (A) to more than 25 years (D). The LCOE for HIT is lowest for array B $(£ 0 \cdot 11 / \mathrm{kWh})$, due to 
optimisation of orientation and tilt angles. Significantly, this is lower than the current day tariff rate for grid import ( $£ 0 \cdot 1173$ ). Due to City Hall's maximum power demand during the afternoon and evening, the SW arrays C and D would be most effective in reducing grid import at peak time (18:00). The current PV FiT rate favours the highest efficiency PV technology investigated, which would encourage a greater take-up of HIT than lower-efficiency alternatives.

During performance monitoring experiments, orientation and shading effects were observed to have a dramatic influence on the response and power output of the PV modules. These parameters require careful optimisation for systems-level design. HIT exhibited higher FF, which did not drop significantly under diffuse sunlight (low irradiance levels typical of the UK climate), unlike $\mathrm{p}$-Si. Additionally, the low power output temperature coefficient (confirmed as $-0 \cdot 28 \% /{ }^{\circ} \mathrm{C}$ in this work) for HIT makes it more suitable than $\mathrm{p}-\mathrm{Si}$ for summertime operation. On technical, environmental and economic grounds, HIT exceeded the performance of the most popularly installed PV technology in the UK, p-Si. Installation of the modelled $88 \mathrm{kWp}$ HIT PV system would improve the EPC for Cardiff City Hall from an E to a D band, avoiding $>40000 \mathrm{~kg}$ of carbon dioxide emissions per annum.

\section{Acknowledgements}

The authors thank Egnitec for the use of PV performance monitoring equipment, the staff at Cardiff City Hall and Cardiff City Council (Adam DeBenedictis), for their assistance in site surveys and for supplying energy tariff data. Thanks are extended to the workshop staff at Cardiff School of Engineering for assistance in setting up the rooftop PV installations for experimentation. Acknowledgements are also extended to the Welsh School of Architecture for access to weather station data. The authors acknowledge the financial support from the UK Energy Research Centre (UKERC), Higher Education Funding Council for Wales (HEFCW), Cardiff University Institute of Energy and the EPSRC SUNTRAP project (EP/K022156/1).

\section{REFERENCES}

BP (British Petroleum) (2010) Solar Module Data. See http:/l www.solarelectricsupply.com/bp-solar-bp380j-solar-panels274 (accessed 12/11/2014).

Bristow N (2013) Egnitec PVMS User Manual. Egnitec, Caernaerfon, UK. See http://www.egnitec.com/ (accessed $16 / 11 / 2015)$.

Carbon Culture (2014) See http://platform.carbonculture.net/ places/city-hall/967/ (accessed 04/01/15).

Cardiff University (2014) Weather Station Data Collected at the Welsh School of Architecture. Cardiff University,
Cardiff, UK. See http://www.cardiff.ac.uk/archi/ meterologicaldata.php (accessed 20/11/2015).

Centre for Alternative Technology (2010) Zero Carbon Britain 2030 - A New Energy Strategy. Centre for Alternative Technology, Wales, UK.

DECC (Department of Energy and Climate Change) (2013) Consultation on the Draft Electricity Market Reform Delivery. DECC, London, UK. See https://www.gov.uk/ government/consultations/consultation-on-the-draftelectricity-market-reform-delivery (accessed 20/11/2014).

DECC (2014a) Feed-in Tariffs. DECC, London, UK. See http:// www.gov.uk/feed-in-tariffs/overview (accessed 12/11/2014).

DECC (2014b) Energy Trends and Prices Statistical Release: 27 November 2014. DECC, London, UK. See http://www.gov.uk/government/news/energy-trends-andprices-statistical-release-27-november-2014 (accessed 27/11/2014).

DECC (2014c) UK Solar PV Strategy Part 2: Delivering a Brighter Future. DECC, London, UK. See http://www.gov. uk/government/uploads/system/uploads/attachment_data/ file/302049/uk_solar_pv_strategy_part_2.pdf (accessed 06/11/2014).

DECC (2014d) Base Electricity Generation Emissions Factors for Company Reporting. DECC, London, UK. See http://www. ukconversionfactorscarbonsmart.co.uk/documents/2014\% 20Emission\%20Factor\%20Methodology $\% 20$ Paper_ FINAL-4Jul14.pdf (accessed 05/01/2015).

Environment Agency (2014) CRC Energy Efficiency Scheme, Guidance for Participants in Phase 2 (2014-2015 to 2018-2019), Version 2. Environment Agency, Bristol, UK. See http:/www.gov.uk/government/uploads/system/ uploads/attachment_data/file/375217/LIT_9008.pdf (accessed 22/12/2014).

Environment Agency (2015) Carbon Reduction Commitment (CRC) Energy Efficiency Scheme, Environment Agency, Bristol, UK. See https://www.gov.uk/guidance/crc-energyefficiency-scheme-qualification-and-registration\#overview (accessed 14/01/2015).

Gupta A, Cemesova A, Hopfe CJ, Rezgui Y and Sweet T (2014) A conceptual framework to support solar PV simulation using an open-BIM data exchange standard. Automation in Construction 37: 166-181.

HM Treasury (2011) The Green Book, Appraisal and Evaluation in Central Government. HM Treasury, London, UK. See http://www.gov.uk/government/uploads/system/ uploads/attachment_data/file/220541/green_book_ complete.pdf (accessed 22/12/2014).

Iftiquar SM, Lee Y, Dao VA et al. (2013) High efficiency heterojunction with intrinsic thin layer solar cell: a short review. In Materials and Processes for Energy: Communicating Current Research and Technological Developments (Mendez-Vilas A (ed.)). Formatex, Korea, pp. 59-67. 
Jenkins N, Ekanayake JB and Strbac G (2010) Distributed Generation, IET Renewable Energy Series 1. Institution of Engineering and Technology, London, UK.

JRC (Joint Research Council) (2006) Approaches and Solar Databases. JRC, European Commission, Brussels, Belgium. See http://re.jrc.ec.europa.eu/pvgis/solrad/index.htm (accessed 13/11/2014).

MeteoSyn (2014) See http://meteosyn.software.informer.com/ (accessed 20/11/2014).

Moselle B, Padilla J and Schmalensee R (2010) Harnessing Renewable Energy in Electric Power Systems: Theory, Practice, Policy. RFF Press, Washington, DC, USA.
Panasonic (2014) VBHN240SJ25 HIT Module Datasheet. Panasonic, Holzkirchen, Germany. See http://eu-solar. panasonic.net (accessed 12/11/2014).

Redahan E (2014) Self-cleaning solar panels - ditching the dirt. Materials World, 1 February. See http://www. iom3.org/materials-world-magazine/news/2014/feb/01/ selfcleaning-solar-panels-ditching-dirt (accessed 20/11/2014).

Valentin EnergieSoftware (2014) $P V^{*} S O L v 7$, Valentin Software, Solar Design Software. Valentin EnergieSoftware, Berlin, Germany. See http://www. valentin-software.com/en (accessed 12/11/2014).

\section{WHAT DO YOU THINK?}

To discuss this paper, please email up to 500 words to the editor at journals@ice.org.uk. Your contribution will be forwarded to the author(s) for a reply and, if considered appropriate by the editorial panel, will be published as discussion in a future issue of the journal.

Proceedings journals rely entirely on contributions sent in by civil engineering professionals, academics and students. Papers should be 2000-5000 words long (briefing papers should be 1000-2000 words long), with adequate illustrations and references. You can submit your paper online via www.icevirtuallibrary.com/content/journals, where you will also find detailed author guidelines. 